\title{
ETV6/RUNX1 Fusion Gene
}

National Cancer Institute

\section{Source}

National Cancer Institute. ETV6/RUNX1 Fusion Gene. NCI Thesaurus. Code C18517.

A fusion gene that results from a chromosomal translocation $\mathrm{t}(12 ; 21)(\mathrm{p} 13 ; \mathrm{q} 22)$ which fuses intron 5 of the ETV 6 gene with intron 2 of the RUNX1 gene. This gene fusion is associated with B-cell lymphoblastic leukemia/lymphoma. 